\title{
Effect of Ionic Liquids on the Physical Properties of the Newly Synthesized Conducting Polymer
}

\author{
Dong Uk Lee, ${ }^{1}$ Jin Yeong Jeong, ${ }^{1}$ Ji Woong Han, ${ }^{1}$ Gi-Chung Kwon, ${ }^{2}$ Pankaj Attri $\left(\mathbb{D},{ }^{2}\right.$ \\ and In Tae Kim $\mathbb{D}^{1}$ \\ ${ }^{1}$ Department of Chemistry, Kwangwoon University, Seoul 139-701, Republic of Korea \\ ${ }^{2}$ Plasma BioScience Research Center/Department of Electrical and Biological Physics, Kwangwoon University, \\ Seoul 139-701, Republic of Korea
}

Correspondence should be addressed to Pankaj Attri; chem.pankaj@gmail.com and In Tae Kim; itkim@kw.ac.kr

Received 23 February 2018; Accepted 8 April 2018; Published 24 June 2018

Academic Editor: Marta Fernández-García

Copyright ( 2018 Dong Uk Lee et al. This is an open access article distributed under the Creative Commons Attribution License, which permits unrestricted use, distribution, and reproduction in any medium, provided the original work is properly cited.

\begin{abstract}
Conducting polymer has many applications in electronics, optical devices, sensors, and so on; however, there is still a massive scope of improvement in this area. Therefore, towards this aim, in this study, we synthesized a new thiophene-based conducting polymer, 2-heptadecyl-5-hexyl-6-(5-methylthiophen-2-yl)-4-(5-((E)-prop-1-enyl)thiophen-2-yl)-5H-pyrrolo[3,4-d]thiazole (HHMPT). Further, to increase its application, the interactions between the conducting polymer (HHMPT) and ionic liquids (ILs) were investigated by UV-Vis spectroscopy, FTIR spectroscopy, and confocal Raman spectroscopy techniques. Moreover, film roughness and conductivity of the polymer film with or without ILs were also studied. The imidazolium- and ammonium family ILs with the potential to interact with the newly synthesized conducting polymer were used. The results of the interaction studies revealed that the imidazolium family IL-polymer mixtures and ammonium family IL-polymer mixtures have almost similar conductivity at low concentration of ILs. This study provides an insight into the combined effect of a polymer and ILs and may generate many theoretical and experimental opportunities.
\end{abstract}

\section{Introduction}

From many years, conducting polymers have been playing a promising role for the fabrication of biochemical and chemical sensors. To fulfill all the criteria, they should have high electrical conductivity, chemical stability, and electrochemical reversibility [1-5]. Polythiophene, polypyrrole, and polyaniline have been used as electrocatalysts for sensing biological and organic molecules from many years [1]. Poly(3,4-ethylenedioxythiophene) (PEDOT) has been reported extensively owing to its ability to promote electron transfer reactions and electroanalysis using conducting film. The PEDOTmodified glassy carbon electrodes were used for detecting dopamine and ascorbic acid [6]. The PEDOT-modified electrodes have also been used for determining pesticides [7]. PEDOT-modified screen-printed carbon electrode is also used for the detection of nitrite [8]. Su and Cheng used the PEDOT-modified screen-printed electrode for the determination of cysteine [9]. Conducting polymer modification is a very good technique, but has limitations because of its low sensitivity [10]. Even though the sensitivity can be improved by the addition of nanomaterials such as $\mathrm{Pd}$ and gold nanoparticles, it still has some limitations [11-13].

Ionic liquids (ILs) are promising materials in the field of chemistry [14-29]. They can be synthesized with various combinations of anion and cation [26-29] and have a wide range of the potential window, good electrochemical stability, and high ionic conductivity $[14,17]$. They can also have the benefits in the variation of various surface properties such as adhesion, wettability, and biocompatibility [30]. IL-based electrodes possess prominent electrochemical properties, for example, carbon paste electrodes are used as pasting binders to detect certain biomolecules [31,32].

The progress of polymer composites has a huge impact on the potential industrial applications and fundamental academic researches. Conducting polymer composites have 
been used for the synthesis of various chemical or biological sensors [33]. However, the interactions between the conducting polymer and IL composite film have not been studied well so far. Therefore, the aims of this study were to develop a new conducting polymer with better physical properties (high thermal stability and better electrochemical properties) and investigate its interaction with ILs to find new possibilities. In this study, we synthesized thiophene-based polymer [2-heptadecyl-5-hexyl-6-(5-methylthiophen-2-yl)-4-(5-((E)prop-1-enyl)thiophen-2-yl)-5H-pyrrolo[3,4-d] thiazole (HHMPT)] and its interaction with various imidazolium and ammonium ILs such as 1-butyl-3-methylimidazolium bromide [Bmim]Br, 1-ethyl-3-methyl-imidazolium-bromide [Emim] Br, triethylammoniummethanesulfonate [TMEAS], and tributylmethylammoniummethyl sulfate [TBMS] ILs was investigated.

\section{Materials and Methods}

2.1. Materials. All the chemicals and reagents required for the synthesis of the polymer and ILs were purchased from Aldrich Chemical Co. (USA). [Bmim]Br, [Emim]Br, and TBMS were purchased from Sigma-Aldrich. Moreover, all the chemicals and reagents were used without any further purification. The rest of the TEMS was synthesized in the laboratory and analyzed by methods described in the literature [34]. Schematic representation of the polymer synthesis is shown in Figure 1.

2.2. Synthesis of Polymer. The reaction of stearic thioamide with (4-hydroxymethyl-2-heptadecyl-thiazol-5-yl)-methanol was performed following the reported method [14].

2.2.1. Synthesis of 4,5-Bis(bromomethyl)-2-heptadecylthiazole. (4-hydroxymethyl-2-heptadecyl-thiazol-5-yl)-methanol $(6.45 \mathrm{~g}, 16.8 \mathrm{mmol})$ was added in $200 \mathrm{~mL}$ of THF, followed by adding pyridine $(1.464 \mathrm{~g}, 18.5 \mathrm{mmol})$ at $0^{\circ} \mathrm{C}$. The reaction mixture was stirred for $5 \mathrm{~min}$, followed by the slow addition of phosphorous tribromide $\left(\mathrm{PBr}_{3}\right)(10 \mathrm{~g}$, $37.0 \mathrm{mmol}$ ). The resulting reaction mixture was stirred for $1 \mathrm{~h}$ at $0^{\circ} \mathrm{C}$ and $5 \mathrm{~h}$ at $\mathrm{RT}$. The reaction mixture was quenched with ice water at $0^{\circ} \mathrm{C}$ and extracted with ether, and the combined ether extract was dried over anhydrous $\mathrm{MgSO}_{4}$, affording 4,5-bis-bromomethyl-2-heptadecyl-thiazole as a white solid in $97 \%$ yield $\left({ }^{1} \mathrm{H} \mathrm{NMR}\left(400 \mathrm{MHz}, \mathrm{CDCl}_{3}\right) \delta 4.68(\mathrm{~s}\right.$, $2 \mathrm{H}), 4.56(\mathrm{~s}, 2 \mathrm{H}), 2.92(\mathrm{t}, 2 \mathrm{H}, J=7.7 \mathrm{~Hz}), 1.76(\mathrm{~m}, 2 \mathrm{H}), 1.25$ $(\mathrm{s}, 28 \mathrm{H}), 0.88(\mathrm{t}, 3 \mathrm{H}, J=6.6 \mathrm{~Hz}) \mathrm{ppm} ;{ }^{13} \mathrm{C} \mathrm{NMR}(100 \mathrm{MHz}$, $\mathrm{CDCl} 3) \delta 171.64,149.47,131.75,33.58,32.45,31.72,30.81$, $29.69,29.27,29.12,28.96,23.93,22.55,21.73$, and 14.03 ppm; FTIR (KBr) v 2922, 2849, 1535, 1487, 1462, 1432,1097 , and $\left.609 \mathrm{~cm}^{-1}\right)$.

2.2.2. Synthesis of 2-Heptadecyl-5-hexyl-5,6-dihydro-4Hpyrrolo[3,4-d]thiazole. 4,5-Bis-bromomethyl-2-heptadecylthiazole $(3.18 \mathrm{~g}, 6.3 \mathrm{mmol}$ ) was dissolved in $80 \mathrm{~mL}$ toluene. To that solution, hexylamine $(1.27 \mathrm{~g}, 12.6 \mathrm{mmol})$ with toluene was added. The resulting solution was maintained at $8^{\circ} \mathrm{C}$ with stirring for $1 \mathrm{~h}$ and further stirred for $48 \mathrm{~h}$ at room temperature. White solid, 2-heptadecyl-5-hexyl-5,6-dihydro- $4 \mathrm{H}$-pyrrolo[3,4-d] thiazole was isolated in $33 \%$ yield after workup $\left({ }^{1} \mathrm{H}-\mathrm{NMR} \quad\left(400 \mathrm{MHz}, \mathrm{CDCl}_{3}\right) \quad \delta \quad 3.97 \quad(\mathrm{~s}, \quad 2 \mathrm{H}\right.$, $J=3.3 \mathrm{~Hz}), 3.89(\mathrm{~s}, 2 \mathrm{H}, J=3.3 \mathrm{~Hz}), 2.96(\mathrm{t}, 2 \mathrm{H}, J=7.7 \mathrm{~Hz})$, $2.77(\mathrm{t}, 2 \mathrm{H}, J=7.6 \mathrm{~Hz}), 1.74(\mathrm{~m}, 2 \mathrm{H}), 1.55(\mathrm{~m} 2 \mathrm{H}), 1.37-$ 1.25 (m, 34H), $0.86(\mathrm{~m}, 6 \mathrm{H}) \mathrm{ppm} ;{ }^{13} \mathrm{C}-\mathrm{NMR}(100 \mathrm{MHz}$, $\left.\mathrm{CDCl}_{3}\right) \delta 175.50,157.85,128.73,56.78,54.81,54.57,34.00$, $31.92,31.78,30.16,29.69,29.66,29.64,29.62,29.59,29.46$, $29.35,29.28,28.99,28.79,26.99,22.69,22.63,14.13$, and $14.07 \mathrm{ppm})$.

2.2.3. Synthesis of 2-Heptadecyl-5-hexyl-5H-pyrrolo[3,4d] thiazole. 2-Heptadecyl-5-hexyl-5,6-dihydro-4H-pyrrolo[3, 4-d]thiazole $(0.93 \mathrm{~g}, 2.07 \mathrm{mmol})$ was added in toluene $(400 \mathrm{~mL})$, followed by dropwise addition of 2,3-dichloro5,6-dicyano-1,4-benzoquinone $(0.52 \mathrm{~g}, 2.28 \mathrm{mmol})$ in $100 \mathrm{~mL}$ toluene at $40^{\circ} \mathrm{C}$ and stirred for $3 \mathrm{~h}$, affording 2-heptadecyl-5-hexyl-5H-pyrrolo[3,4-d]thiazole as a white solid in $99 \%$ yield ( ${ }^{1} \mathrm{H}-\mathrm{NMR}\left(400 \mathrm{MHz}, \mathrm{CDCl}_{3}\right) \delta 6.94(\mathrm{~d}, 1 \mathrm{H}$, $J=1.9 \mathrm{~Hz}), 6.55(\mathrm{~d}, 1 \mathrm{H}, J=1.9 \mathrm{~Hz}), 3.92(\mathrm{t}, 2 \mathrm{H}, J=7.2 \mathrm{~Hz})$, $2.88(\mathrm{t}, 2 \mathrm{H}, J=7.7 \mathrm{~Hz}), 1.75(\mathrm{~m}, 4 \mathrm{H}), 1.32(\mathrm{~m}, 2 \mathrm{H}), 1.24-$ $1.22(\mathrm{~m}, 32 \mathrm{H}), 0.82(\mathrm{~m}, 6 \mathrm{H}) \mathrm{ppm} ;{ }^{13} \mathrm{C}-\mathrm{NMR}(100 \mathrm{MHz}$, $\left.\mathrm{CDCl}_{3}\right) \delta 171.74,107.54,107.44,51.23,34.57,31.93,31.72$, 31.36, 29.68, 29.48, 29.43, 29.34, 29.20, 26.37, 22.66, 22.47, 14.04, and $13.92 \mathrm{ppm}$; FTIR (KBr) v 3179, 2957, 2921, 2050, 1529, 1470,1390, 1215, 1149, 1089, 752, 717, 629, and $590 \mathrm{~cm}^{-1}$ ).

2.2.4. Synthesis of 4,6-Dibromo-2-heptadecyl-5-hexyl-5H-pyrrolo[3,4-d] thiazole. 2-Heptadecyl-5-hexyl-5H-pyrrolo[3,4-d] thiazole $(0.5 \mathrm{~g}, 1.11 \mathrm{mmol})$ was dissolved in $25 \mathrm{~mL}$ anhydrous dichloromethane. To that solution, a solution of $\mathrm{N}$ bromosuccinimide (NBS) $(0.398 \mathrm{~g}, 2.22 \mathrm{mmol})$ in $10 \mathrm{~mL}$ $\mathrm{MC}$ was added at $-5^{\circ} \mathrm{C}$. The reaction mixture was poured in water and extracted with dichloromethane. The organic extract was washed with water, followed by brine, dried over anhydrous $\mathrm{MgSO}_{4}$, filtered, and concentrated, affording 4,6dibromo-2-heptadecyl-5-hexyl-5H-pyrrolo[3,4-d]thiazole as a white solid in $88 \%$ yield $\left({ }^{1} \mathrm{H}-\mathrm{NMR}\left(400 \mathrm{MHz}, \mathrm{CDCl}_{3}\right) \delta\right.$ $4.10(\mathrm{t}, 2 \mathrm{H}, J=7.7 \mathrm{~Hz}), 2.95(\mathrm{t}, 2 \mathrm{H}, J=7.7 \mathrm{~Hz}), 1.76(\mathrm{~m}, 4 \mathrm{H})$, 1.33-1.25 (m, 34H) $0.87 \quad(\mathrm{~m}, 6 \mathrm{H}) \quad \mathrm{ppm} ;{ }^{13} \mathrm{C}-\mathrm{NMR}$ $\left(100 \mathrm{MHz}, \mathrm{CDCl}_{3}\right) \delta 173.22,146.17,119.71,87.64,86.97$, $49.39,48.19,34.91,34.76,34.61,31.91,31.31,30.63,30.44$, $30.26,29.68,29.58,29.48,29.44,29.15,29.02,28.62,26.11$, $22.68,22.48,14.19,14.04,14.02$, and $13.87 \mathrm{ppm}$; FTIR $(\mathrm{KBr}) v$ 2957, 2824, 2851, 1533, 1464, 1330, 1129, 1064, $883,782,653$, and $\left.604 \mathrm{~cm}^{-1}\right)$.

2.2.5. Synthesis of 2-Heptadecyl-5-hexyl-4,6-di(thiophen-2yl)-5H-pyrrolo[3,4-d]thiazole. 4,6-Dibromo-2-heptadecyl-5hexyl-5H-pyrrolo[3,4-d]thiazole $(0.4566 \mathrm{~g}, 0.75 \mathrm{mmol})$ and tributyl(thiophen-2-yl)stannane $(0.734 \mathrm{~g}, 1.96 \mathrm{mmol})$ were added in $5 \mathrm{~mL}$ toluene, followed by adding $\mathrm{Pd}\left(\mathrm{PPh}_{3}\right)_{4}$. The reaction mixture was stirred to make a clear solution and refluxed for $48 \mathrm{~h}$. The reaction mixture was cooled affording 2-heptadecyl-5-hexyl-4,6-di(thiophen-2-yl)-5H-pyrrolo[3,4d] thiazole as a white solid in $40 \%$ yield $\left({ }^{1} \mathrm{H}-\mathrm{NMR}(400 \mathrm{MHz}\right.$, $\left.\mathrm{CDCl}_{3}\right) \delta 7.40(\mathrm{~d}, 2 \mathrm{H}, J=4.4 \mathrm{~Hz}), 7.34(\mathrm{~d}, 1 \mathrm{H}, J=4.7 \mathrm{~Hz}), 7.15$ $(\mathrm{m}, 3 \mathrm{H}), 4.38(\mathrm{t}, 2 \mathrm{H}, \mathrm{J}=7.9 \mathrm{~Hz}), 3.02(\mathrm{t}, 3 \mathrm{H}, J=7.3 \mathrm{~Hz}), 1.86-$ $1.68(\mathrm{~m}, 4 \mathrm{H}), 1.45-1.20(\mathrm{~m}, 34 \mathrm{H}), 0.88(\mathrm{~m}, 6 \mathrm{H}) \mathrm{ppm} ;{ }^{13} \mathrm{C}-$ NMR $\left(100 \mathrm{MHz}, \mathrm{CDCl}_{3}\right) \delta 173.12,147.15,132.02,127.57$, 
<smiles>[B]Cc1nc(C[B])c(C[B])s1</smiles>

1

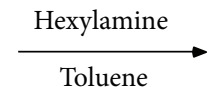

Toluene<smiles>CC(C)c1nc2cn(-c3ccccc3)cc2s1</smiles><smiles>CCC(C)C</smiles>

3

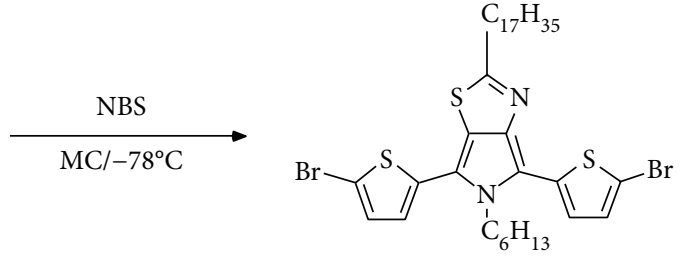

6

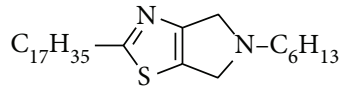

2

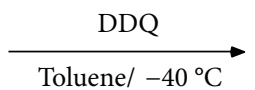

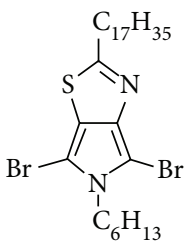

4

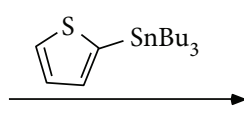

$\mathrm{Pd}\left(\mathrm{PPH}_{3}\right)_{4}$, Toluene

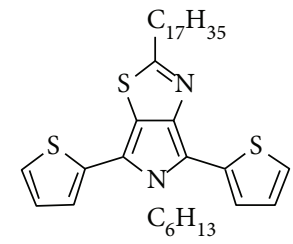

5
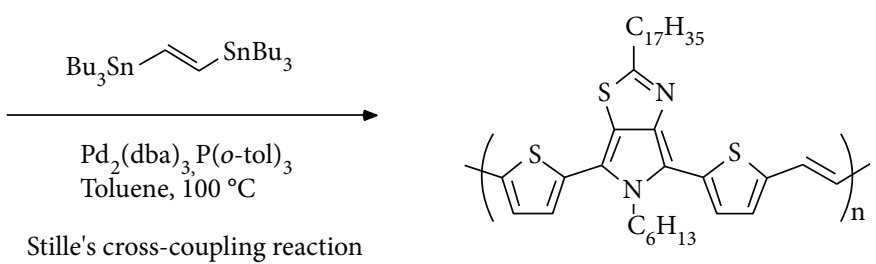

Polymer

FIGURE 1: Schematic representation for the synthesis of new conducting polymer.

$127.49,127.26,125.65,125.10,124.52,120.05,115.59,101.97$, $93.23,87.90,60.08,48.84,39.65,36.16,34.80,31.92,31.34$, $31.11,29.62,29.48,29.35,29.22,28.79,26.21,26.09,22.69$, $22.42,14.12$, and $13.91 \mathrm{ppm})$.

2.2.6. Synthesis of 4,6-Bis(5-bromothiophen-2-yl)-2heptadecyl-5-hexyl-5H-pyrrolo[3,4-d]thiazole. 2-Heptadecyl-5-hexyl-4,6-di(thiophen-2-yl)-5H-pyrrolo[3,4-d] thiazole $(0.2 \mathrm{~g}, 0.33 \mathrm{mmol})$ was added in $20 \mathrm{~mL}$ MC. NBS $(0.121 \mathrm{~g}$, $0.68 \mathrm{mmol}$ ) was dissolved in $15 \mathrm{~mL} \mathrm{MC}$, and the solution was cooled to $10^{\circ} \mathrm{C}$. White solid 4,6-bis(5-bromothiophen-2-yl)-2-heptadecyl-5-hexyl-5H-pyrrolo[3,4-d] thiazole was obtained in $80 \%$ yield following the standard workup procedure $\left({ }^{1} \mathrm{H}-\mathrm{NMR}\left(400 \mathrm{MHz}, \mathrm{CDCl}_{3}\right) \delta 7.08(\mathrm{~s}, 2 \mathrm{H})\right.$, $7.07(\mathrm{~d}, 1 \mathrm{H}, J=3.9 \mathrm{~Hz}), 6.88(\mathrm{~d}, 1 \mathrm{H}, J=3.9 \mathrm{~Hz}), 4.28(\mathrm{t}$, $2 \mathrm{H}, J=7.8 \mathrm{~Hz}), 3.00(\mathrm{t}, 2 \mathrm{H}, J=7.7 \mathrm{~Hz}), 1.81(\mathrm{~m}, 2 \mathrm{H}), 1.68$ $(\mathrm{m}, 2 \mathrm{H}), 1.42(\mathrm{~m}, 2 \mathrm{H}), 1.32-1.21(\mathrm{~m}, 34 \mathrm{H}), 0.87(\mathrm{~m}$, $6 \mathrm{H}) \mathrm{ppm} ;{ }^{13} \mathrm{C}-\mathrm{NMR}\left(100 \mathrm{MHz}, \mathrm{CDCl}_{3}\right) \delta 173.19,147.50$, $135.54,133.50,130.52,130.47,127.43,125.79,114.82$, $112.51,111.46,46.55,34.72,31.85,31.02,29.63,29.54$, $29.29,29.12,25.98,22.61,22.34,14.05$, and $13.83 \mathrm{ppm})$.

2.2.7. Synthesis of Polymer. 4,6-Bis(5-bromothiophen-2-yl)2-heptadecyl-5-hexyl-5H-pyrrolo[3,4-d]thiazole (0.174 g, $0.22 \mathrm{mmol}$ ) was added in toluene $(4 \mathrm{~mL})$, followed by adding trans-1,2-bis(tributylstannyl)ethene $(0.137 \mathrm{~g}, 0.22 \mathrm{mmol})$, $\mathrm{Pd}_{2}(\mathrm{dba})_{3}(0.004 \mathrm{~g}, 0.004 \mathrm{mmol})$, and $\mathrm{p}(\mathrm{o}-\mathrm{tol})_{3}(0.0055 \mathrm{~g}$, $0.0181 \mathrm{mmol})$ in $2 \mathrm{~mL}$ toluene. The resulting reaction mixture was stirred for $5 \mathrm{~h}$. Excess of trans-1,2-bis(tributylstannyl)ethane was added and further stirred for $1 \mathrm{~h}$, followed by adding excess of 2-bromothiophene and stirring for $1 \mathrm{~h}$. The solution was then washed with chloroform and evaporated under vacuum. The obtained polymer has $\mathrm{Mn} \sim 33,093, \mathrm{Mw} \sim 36,765$, and $\mathrm{PD} 1.11 \quad\left({ }^{1} \mathrm{H}-\mathrm{NMR}\right.$ $\left(400 \mathrm{MHz} \mathrm{CDCl}_{3}\right) \delta 7.39(\mathrm{br}, 3 \mathrm{H}), 7.06$ (br, $\left.1 \mathrm{H}\right), 7.05$ (br, $2 \mathrm{H}), 4.50$ (br, 2H), 3.06 (br, 2H), 2.05 (br, 2H), 1.87 (br, $4 \mathrm{H}), 1.26(\mathrm{~s}, 34 \mathrm{H})$, and $0.88(\mathrm{~s}, 6 \mathrm{H}) \mathrm{ppm})$.

2.3. Measurements. ${ }^{1} \mathrm{H}$ NMR and ${ }^{13} \mathrm{C}$ NMR spectra were obtained using a JEOL MSL 300 spectrometer and used to identify the structure of the synthesized compounds. Polystyrene standards in tetrahydrofuran solutions were utilized as the standards for gel permeation chromatography. S-3100 $\mathrm{UV}-\mathrm{V}$ is spectrophotometer with the following features was used: wavelength resolution, $0.95 \mathrm{~nm}$; wavelength accuracy, $\pm 0.5 \mathrm{~nm}$; and wavelength reproducibility, $\pm 0.02 \mathrm{~nm}$. FTIR spectra were recorded using a Bomem MB Series MB100 FTIR spectrometer. Electrical conductivity was measured using a standard four-in-line probe apparatus. The thickness of the polymer thin films was measured using an Alpha-Step profilometer. Raman spectra were measured at room temperature using a confocal Raman microscope (WITec, Alpha $300 \mathrm{R}$ ) equipped with a $632.8 \mathrm{~nm} \mathrm{He}-\mathrm{Ne}$ laser. In addition, AFM studies were performed using Park systems, model: XE-100 with noncontract measuring mode.

2.4. Sample Preparation. A small amount $(0.001 \mathrm{~g})$ of the polymer was dissolved in $4 \mathrm{~mL}$ of chloroform. Later, 1, 2, and $5 \mathrm{wt} \%$ of ILs were dissolved in this polymer-chloroform mixture at room temperature and this mixture was then vigorously stirred for $1 \mathrm{~h}$ at $20^{\circ} \mathrm{C}$. Subsequently, the polymer solutions with or without ILs were cast on clean glass plates (150 $\mu \mathrm{m}$ thickness) and then dried under vacuum. These films were used for various spectroscopy studies. 


\section{Results and Discussion}

3.1. Study of Interactions between Polymer and ILs by UV-Vis Spectroscopy at Various Temperatures. A new thiophenebased conducting polymer, 2-heptadecyl-5-hexyl-6-(5methylthiophen-2-yl)-4-(5-((E)-prop-1-enyl)thiophen-2-yl) -5H-pyrrolo[3,4-d] thiazole (HHMPT), was synthesized, as shown in Figure 1. The mechanical and conducting properties of polymer-IL mixtures depend on the miscibility of the polymer in ILs; hence, determining this aspect is very important. Further, molecular interactions between the polymer and ILs were measured by mixing them. UV-Vis spectroscopy may aid in elucidating these interactions. The UV-Vis spectra of the polymer at $20^{\circ} \mathrm{C}$ shows a peak at $\sim 530 \mathrm{~nm}$, reflecting the conjugated $\pi$-systems (Figure 2). However, after the addition of different ILs such as [Bmim]Br, [Emim]Br, TMEAS, and TBMS, the polymer peak at $\sim 530 \mathrm{~nm}$ disappeared and other peaks originated for all the ILs-polymer mixtures.

The polymer $+[\mathrm{Bmim}] \mathrm{Br}$ showed new peaks at $\sim 425$ and $\sim 724 \mathrm{~nm}$. A small hump also appeared at $\sim 654 \mathrm{~nm}$ for polymer $+[\mathrm{Bmim}] \mathrm{Br}$. In the presence of $[\mathrm{Emim}] \mathrm{Br}$ IL and polymer mixtures, the new peak appears at $\sim 423 \mathrm{~nm}$ and $\sim 724 \mathrm{~nm}$ for the polymer $+[$ Emim $] \mathrm{Br}$ and a small hump at $\sim 657 \mathrm{~nm}$, similar to the polymer $+[\mathrm{Bmim}] \mathrm{Br}$ mixtures, whereas for the ammonium ILs TMEAS and TBMS, a similar pattern of the peaks was observed. For polymer + TMEAS, the peaks appear at $\sim 423$ and $\sim 728 \mathrm{~nm}$ and hump at $\sim 660 \mathrm{~nm}$. However, for the polymer + TBMS mixture, new peaks at $\sim 424$ and $\sim 728 \mathrm{~nm}$ and hump at $\sim 660 \mathrm{~nm}$ appeared. In both the families of ILs, similar peaks and a hump appeared, indicating approximately similar interactions or reaction occurs in the polymer in the presence of ILs. Although, in the presence of ammonium ILs + polymer, the peak and hump at $\sim 728 \mathrm{~nm}$ and $\sim 660 \mathrm{~nm}$, respectively, slightly red shifted as compared to those in imidazolium ILs + polymer mixture. The peaks at $\sim 420 \mathrm{~nm}$ correspond to the $\pi-\pi^{*}$ transitions, and peak at $\sim 700 \mathrm{~nm}$ resembles either an aggregation state of a conformation or arrangement of the polymer chains that are changing upon the addition of ILs.

3.2. Study of Interactions between Conducting Polymer and ILs by Using FT-IR and Confocal Raman Spectroscopies. FTIR spectroscopy is another important tool for studying the interactions between the polymer and ILs [35]. FTIR spectra of the conducting polymer were recorded with or without ILs, as shown in Figure 3. Some peak shifts in the FTIR spectra were obtained after the interaction of polymer with the ILs. The FTIR peaks at $\sim 2922$ and $2851 \mathrm{~cm}^{-1}$ may be due to the alkyl chain of the polymer, and the peaks at 1637 and $1495 \mathrm{~cm}^{-1}$ may originate because of the aromatic $-\mathrm{C}=\mathrm{C}$ - bond stretching of the polymer. The peak at $\sim 1100 \mathrm{~cm}^{-1}$ may be due to the $=\mathrm{C}-\mathrm{H}$ groups. After the interaction of $[\mathrm{Bmim}] \mathrm{Br}$ (1 wt\%) with the conducting polymer, the peaks are mainly due to the alkyl chain shifts to longer wavelength at 2964 and $2875 \mathrm{~cm}^{-1}$. Moreover, the peaks due to the $-\mathrm{C}=\mathrm{C}$ - bond of the polymer shifted to $\sim 1601$ and $1521 \mathrm{~cm}^{-1}$. These peak shifts in the composite film of polymer and [Bmim]Br IL ( $1 \mathrm{wt} \%)$ reveal the possible interactions between them. The peak shift for the other [Emim]Br(imidazolium IL) (1 wt\%) and polymer is approximately same as that for the [Bmim] $\mathrm{Br}$ $\mathrm{IL}$ and polymer. The intensity of the $\mathrm{C}-\mathrm{H}\left(\mathrm{sp}^{3}\right)$ and aromatic $\mathrm{C}=\mathrm{C}$ stretching decreased for the polymer-TMEAS (1 wt\%) mixtures; however, for other ammonium IL (TBMS) (1 wt\%) polymer mixture, the peak shift is more for aromatic $\mathrm{C}=\mathrm{C}$ stretching. However, no change in peak shift was observed with the increase in IL concentration (data not shown). These shifts occurred because of the interaction of polymer with the ILs. There can be H-bonding between the anions of ILs and polymer, or other interactions such as van der Wall interactions are also possible between the ILs and polymer. To understand more exact interactions between the ILs and the polymer, the study is ongoing and will be reported in the near future.

Another sophisticated technique such as confocal Raman spectroscopy was used to investigate the interactions between the polymer and ILs (1 wt \%). The polymer film was not damaged during the confocal Raman spectroscopy, because of its highly selective and sensitive laser. As shown in Figure 4, a significant peak appeared at $1453 \mathrm{~cm}^{-1}$, corresponding to the $\beta(\mathrm{C}-\mathrm{H})$ in the polymer. In contrast, the polymer $+[\mathrm{Bmim}] \mathrm{Br}$ showed the peaks at $1025,1113,1341$, and $1421 \mathrm{~cm}^{-1}$ corresponding to the $\gamma(\mathrm{C}-\mathrm{C}-\mathrm{C}), \gamma(\mathrm{C}-\mathrm{O}), \mathrm{C}-\mathrm{N}^{+}$, and $\beta(\mathrm{C}-\mathrm{H})$, respectively, whereas the polymer $+[\mathrm{Emim}] \mathrm{Br}$ showed the peaks at 956, $1086,1336,1422$, and $1567 \mathrm{~cm}^{-1}$ corresponding to the $(\beta(\mathrm{C}-\mathrm{O}), \quad \mathrm{C}-\mathrm{C}), \quad(\gamma(\mathrm{C}-\mathrm{C}-\mathrm{C})), \quad(\mathrm{C}-\mathrm{N}+), \quad(\beta(\mathrm{C}-\mathrm{H}))$, and $(\gamma(\mathrm{NC})+\gamma(\mathrm{NH}))$, respectively. In both cases, the peak at $1453 \mathrm{~cm}^{-1}$ corresponding to $\beta(\mathrm{C}-\mathrm{H})$ shifted to 1422 and $1421 \mathrm{~cm}^{-1}$ for polymer $+[$ Emim $] \mathrm{Br}$ and polymer $+[\mathrm{Bmim}] \mathrm{Br}$, respectively, probably because of the interaction of polymer and ILs. Later, the polymer and TBMS complex showed peaks at 978,1052 , and $1428 \mathrm{~cm}^{-1}$ corresponding to the $\mathrm{C}-\mathrm{H}, \gamma(\mathrm{C}-$ C-C), and $-\mathrm{CH}_{2}$, respectively. The polymer + TMEAS shows peaks at $951,1049,1425$, and $1456 \mathrm{~cm}^{-1}$ corresponding to the $\beta(\mathrm{C}-\mathrm{O}), \mathrm{C}-\mathrm{C}), \gamma(\mathrm{C}-\mathrm{C}-\mathrm{C}), \beta(\mathrm{C}-\mathrm{H})$, and $\beta(\mathrm{C}-\mathrm{H})$, respectively. Similar to the FTIR spectroscopy, no peak shift was observed in confocal Raman spectroscopy with the increase in the concentration of ILs (data not shown).

3.3. Effect of the Polymer and IL Interaction on the Conductivity and Surface Roughness Measurements. Recently, there has been a keen interest in enhancing the conductivity of polymer. Such enhanced conductivity can be achieved by adding secondary dopants or additives such as diethylene glycol, 2-nitroethanol, glycerol, dimethyl sulfoxide, and tetrahydrofuran [36, 37]. However, this method has many drawbacks. Therefore, we attempted to enhance the conductivity of polymer by utilizing ILs. Our experimental results mentioned above clearly indicate good interaction between the polymer and ILs, suggesting a significant possibility of enhancing the conductivity of polymer by utilizing ILs. The experimental conductivity data listed in Table 1 demonstrate that the polymer has a very good conductivity $\left(\mathrm{I}_{2}\right.$ doped) of $\approx 4.0 \pm 0.9 \times 10^{-2} \mathrm{~S} \mathrm{~cm}^{-1}$ at $20^{\circ} \mathrm{C}$. The addition of ILs was found to increase or decrease the conductivity depending upon the IL properties. 

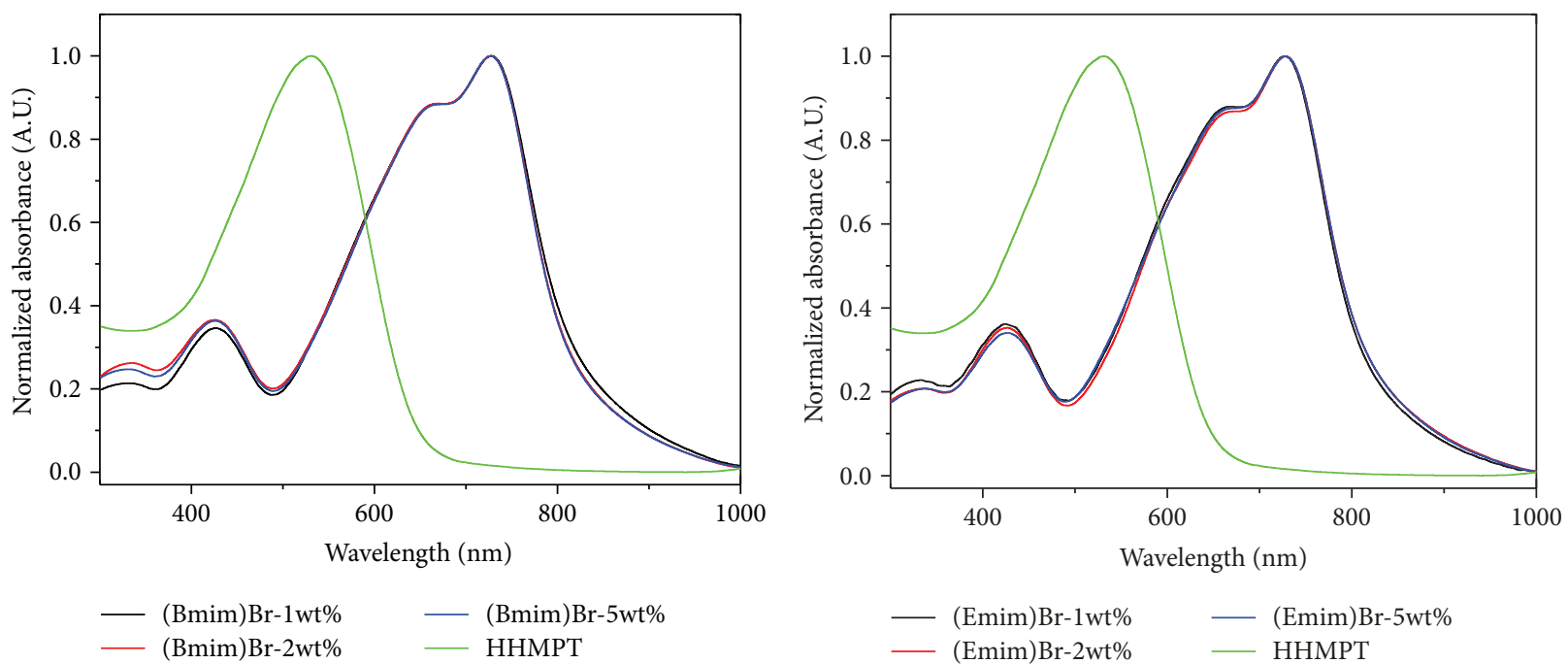

(a)
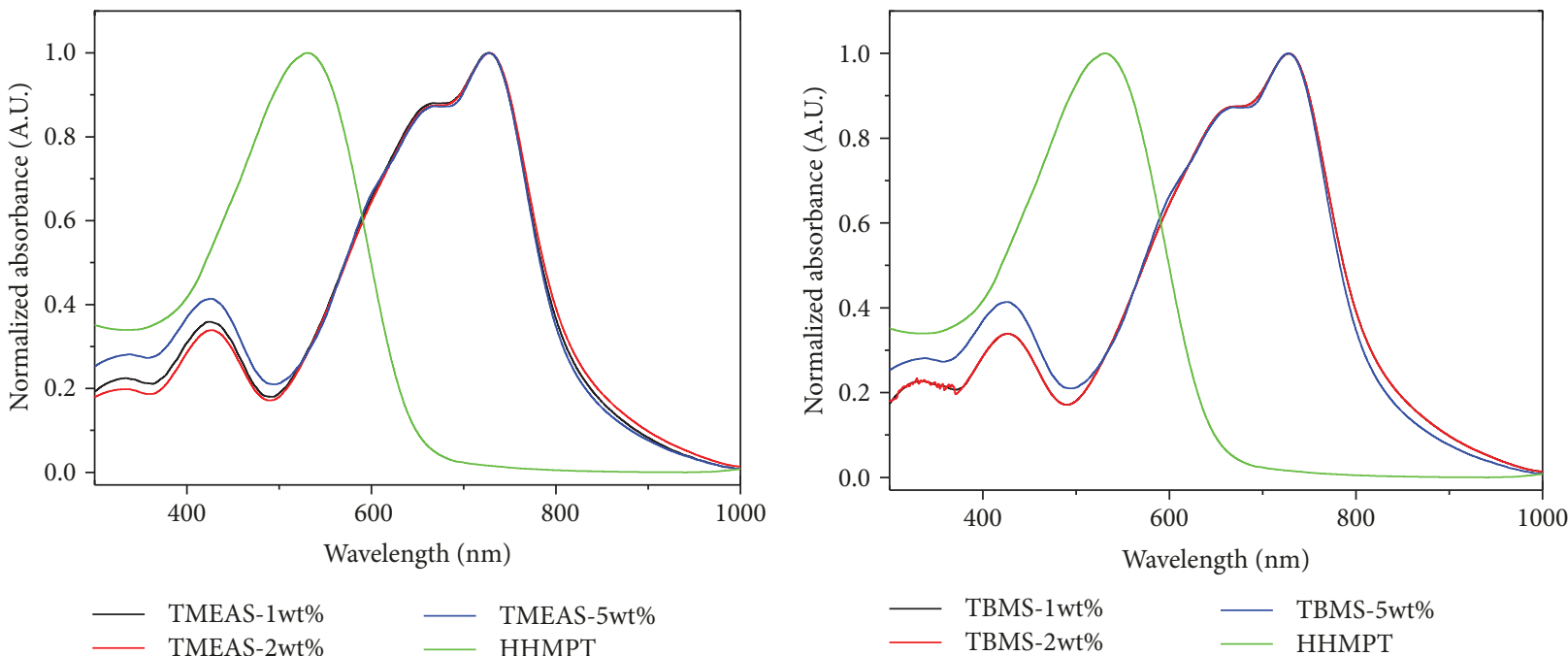

(d)

FIGURE 2: UV-Vis spectra of the polymer and polymer + ILs (1, 2, and $5 \mathrm{wt} \%)$ mixtures: (a) polymer + [Bmim]Br; (b) polymer + [Emim]Br; (c) polymer + TMEAS; (d) polymer + TBMS.

The conductivity of ammonium ILs + polymer $\left(\mathrm{I}_{2}\right.$ doped $)$ measured is as follows: polymer + TMEAS is 1.6 $\pm 0.8 \times 10^{-1} \mathrm{Scm}^{-1}$ and polymer+TBMS is $1.2 \pm 0.7 \times$ $10^{-1} \mathrm{~S} \mathrm{~cm}^{-1}$ at $1 \mathrm{wt} \%$, but with increasing content of the ILs to $5 \mathrm{wt} \%$, the conductivity decreases to $1.3 \pm 0.7 \times 10^{-1}$ and $7.2 \pm 0.2 \times 10^{-2} \mathrm{~S} \mathrm{~cm}^{-1}$ for polymer + TMEAS and polymer + TBMS, respectively, as listed in Table 1. For imidazolium ILs ( $\mathrm{I}_{2}$ doped), the conductivities are as follows: $[\mathrm{Bmim}] \mathrm{Br}$ + polymer, $2.1 \pm 0.2 \times 10^{-1} \mathrm{~S} \mathrm{~cm}^{-1}$; [Emim] Br + polymer, 1.8 $\pm 0.9 \times 10^{-1} \mathrm{~S} \mathrm{~cm}^{-1}$ for $1 \mathrm{wt} \%$ of IL, whereas the conductivity values are $1.9 \pm 0.2 \times 10^{-1} \mathrm{Scm}^{-1}$ and $9.9 \pm 0.7 \times 10^{-2} \mathrm{Scm}^{-1}$ for $5 \mathrm{wt} \%$ of polymer $+[\mathrm{Bmim}] \mathrm{Br}$ and polymer $+[\mathrm{Emim}] \mathrm{Br}$, respectively. These results show that the conductivity does not change significantly with the change in ILs (at lower concentrations), while the conductivity decreases with increase in the concentration for [Emim] Br and TBMS ILs. Although, the conductivity of polymer-[Bmim]Br IL film does not change with the increase in the IL concentration. The surface roughness of polymer and polymer + ILs can be understood by atomic-force microscopy (AFM). The surface roughness of the polymer alone is $4 \pm 0.696 \mathrm{~nm}$, as shown in Figure S1S3, whereas with the addition of the ILs (1 wt\%) such as [Bmim] Br, [Emim] Br, TMEAS, and TBMS, the average roughnesses were $0.5 \pm 0.617,1.9 \pm 0.350,3.1 \pm 0.809$, and 0.6 $\pm 0.472 \mathrm{~nm}$, respectively (Figure S1). However, the average roughnesses were $1.2 \pm 0.617,2.7 \pm 0.350,71 \pm 0.809$, and 3.4 $\pm 0.472 \mathrm{~nm}$, in the presence of polymer $+[\mathrm{Bmim}] \mathrm{Br}(2 \mathrm{wt} \%)$, $+[$ Emim $] \mathrm{Br}(2 \mathrm{wt} \%),+$ TMEAS (2 $\mathrm{wt} \%)$, and +TBMS (2 wt\%), respectively (Figure S2). And the average roughnesses for the polymer $+[\mathrm{Bmim}] \mathrm{Br}(5 \mathrm{wt} \%),+[\mathrm{Emim}] \mathrm{Br} \quad(5 \mathrm{wt} \%)$, + TMEAS $(5 \mathrm{wt} \%$ ), and +TBMS (5 wt\%) were $2.4 \pm 0.617$, $41.7 \pm 0.350,114.9 \pm 0.809$, and $4.4 \pm 0.472 \mathrm{~nm}$, respectively (Figure S3). The above AFM data show that [Bmim]Br IL shows the least roughness among all the studied systems, including the polymer (without IL mixtures). ILs may induce the formation of a three-dimensional conducting 


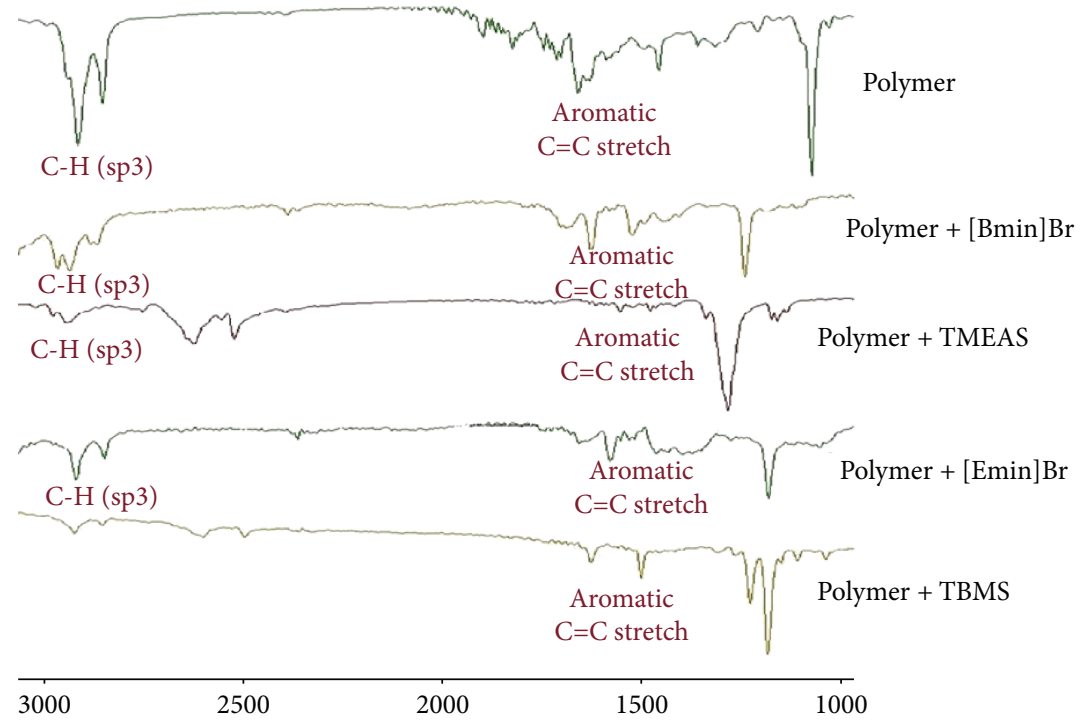

FIGURE 3: FTIR spectra of the polymer and polymer-IL (1 wt $\%)$ mixtures.

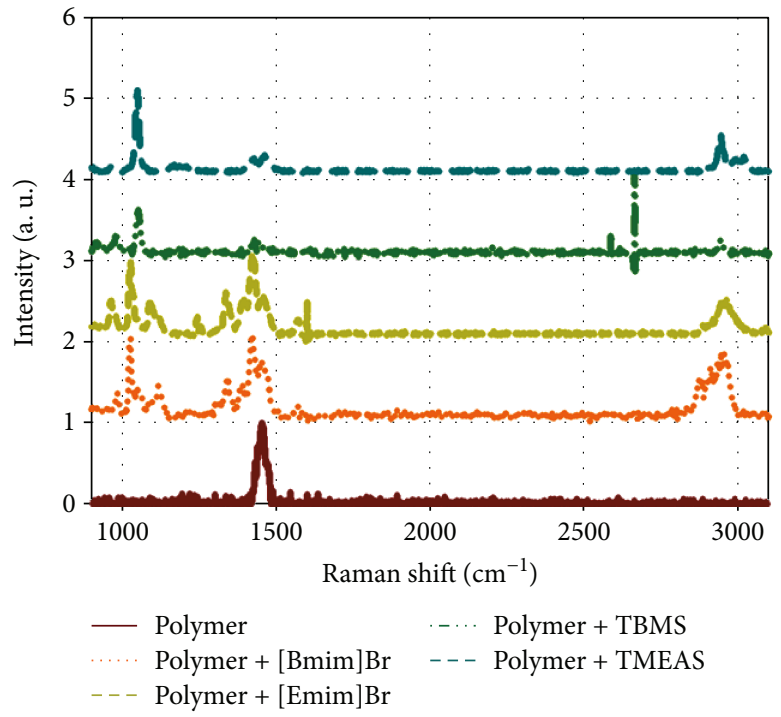

Figure 4: Confocal Raman spectroscopy data of polymer and polymer-IL (1 wt\%) mixtures.

TABLE 1: Conductivity of polymer and polymer-IL mixture ( $\mathrm{I}_{2}$ doped).

\begin{tabular}{|c|c|c|c|c|}
\hline \multirow{2}{*}{ Sample } & \multirow[b]{2}{*}{$0 \mathrm{wt} \%$} & \multicolumn{3}{|c|}{ Conductivity $(\mathrm{S} / \mathrm{cm})$} \\
\hline & & $1 \mathrm{wt} \%$ & $2 \mathrm{wt} \%$ & $5 \mathrm{wt} \%$ \\
\hline Polymer & $4.0 \pm 0.9 \times 10^{-2}$ & & & \\
\hline Polymer $+[\mathrm{Bmim}] \mathrm{Br}$ & & $2.1 \pm 0.2 \times 10^{-1}$ & $2.0 \pm 0.3 \times 10^{-1}$ & $1.9 \pm 0.2 \times 10^{-1}$ \\
\hline Polymer $+[$ Emim $] \mathrm{Br}$ & & $1.8 \pm 0.9 \times 10^{-1}$ & $1.7 \pm 0.8 \times 10^{-1}$ & $9.9 \pm 0.7 \times 10^{-2}$ \\
\hline Polymer + TMEAS & & $1.6 \pm 0.8 \times 10^{-1}$ & $1.4 \pm 0.7 \times 10^{-1}$ & $1.3 \pm 0.7 \times 10^{-1}$ \\
\hline Polymer + TBMS & & $1.2 \pm 0.7 \times 10^{-1}$ & $9.9 \pm 0.7 \times 10^{-2}$ & $7.2 \pm 0.2 \times 10^{-2}$ \\
\hline
\end{tabular}

network using the polymer domains [38], resulting in increasing the conductivity of polymer + ILs. Timoshevskii et al. concluded that the presence of a small roughness in the structures drastically reduces the electrical conductivity [39]. Hence, the presence of imidazolium and ammonium ILs in low concentration helps in the development of smooth surface of film that results in the increase of conductivity. 
The new synthesized polymer HHMPT has good solubility in chloroform along with high conductivity of 4.0 $\pm 0.9 \times 10^{-2} \mathrm{Scm}^{-1}$ at $20^{\circ} \mathrm{C}$. Moreover, the presence of electron-rich thiophene with electron-deficient thiazole, in our newly synthesized polymer, opens the door for the application in solar cells, OLED, transistors, and sensors. However, we have not studied these possible applications of our polymer, but based on the literature, the polymers with electron-donating heterocycles and an electron-accepting building block are capable materials for photovoltaic applications [40, 41]. Moreover, after the combination of polymer with ILs, we are excepting high possibilities of this material for application in photovoltaics.

\section{Conclusions}

A new conducting polymer was synthesized, and its physical properties were studied with or without ILs. In addition, the conductivity and interaction level between the polymer and ILs were found to be dependent on the ILs. The polymer with [Bmim] Br IL exhibited the least roughness and higher conductivity even at higher IL concentrations, probably because of strong interactions with the polymer, while the conductivity of polymer decreases with increase in concentration of TBMS IL. This study shows new possible interactions of polymer and ILs and also opens new possibilities in different fields.

\section{Conflicts of Interest}

The authors declare no conflict of interest.

\section{Acknowledgments}

This work was supported by the Korea Institute of Energy Technology Evaluation and Planning (KETEP) and the Ministry of Trade, Industry \& Energy (MOTIE) of the Republic of Korea (20173030014460) and by the Kwangwoon University (2018).

\section{Supplementary Materials}

Figure S1: AFM images of the polymer and polymer-IL (1 wt\%) mixtures: (a) polymer; (b) polymer + [Bmim]Br; (c) polymer $+[\mathrm{Emim}] \mathrm{Br}$; (d) polymer + TMEAS; and (e) polymer+TBMS. Figure S2: AFM images of the polymer and polymer-IL (2 wt\%) mixtures: (a) polymer + [Bmim]Br; (b) polymer $+[$ Emim $] \mathrm{Br}$; (c) polymer + TMEAS; and (d) polymer + TMEAS. Figure S3: AFM images of the polymer and polymer-IL (5 wt\%) mixtures: (a) polymer $+[\mathrm{Bmim}] \mathrm{Br}$; (b) polymer + [Emim]Br; (c) polymer + TMEAS; and (d) polymer + TMEAS. (Supplementary Materials)

\section{References}

[1] U. Lange, N. V. Roznyatovskaya, and V. M. Mirsky, "Conducting polymers in chemical sensors and arrays," Analytica Chimica Acta, vol. 614, no. 1, pp. 1-26, 2008.

[2] H. Ago, K. Petritsch, M. S. P. Shaffer, A. H. Windle, and R. H. Friend, "Composites of carbon nanotubes and conjugated polymers for photovoltaic devices," Advanced Materials, vol. 11, no. 15, pp. 1281-1285, 1999.

[3] G. Gustafsson, Y. Cao, G. M. Treacy, F. Klavetter, N. Colaneri, and A. J. Heeger, "Flexible light-emitting diodes made from soluble conducting polymers," Nature, vol. 357, no. 6378, pp. 477-479, 1992.

[4] T. A. Skotheim, R. L. Elsenbaumer, and J. R. Reynolds, Handbook of Conducting Polymers, Marcel Dekker, New York, NY, USA, 2nd edition, 2007.

[5] P. Attri, D. H. Park, S. H. Lee et al., "Physicochemical properties of polyaniline-ionic liquid mixtures and their application in dye-sensitized solar cells," Science of Advanced Materials, vol. 7, no. 12, pp. 2583-2595, 2015.

[6] V. S. Vasantha and S.-M. Chen, "Electrocatalysis and simultaneous detection of dopamine and ascorbic acid using poly(3,4-ethylenedioxy)thiophene film modified electrodes," Journal of Electroanalytical Chemistry, vol. 592, no. 1, pp. 77-87, 2006.

[7] P. Manisankar, S. Viswanathan, A. M. Pusphalatha, and C. Rani, "Electrochemical studies and square wave stripping voltammetry of five common pesticides on poly 3,4-ethylenedioxythiophene modified wall-jet electrode," Analytica Chimica Acta, vol. 528, no. 2, pp. 157-163, 2005.

[8] C.-Y. Lin, V. S. Vasantha, and K.-C. Ho, "Detection of nitrite using poly(3,4-ethylenedioxythiophene) modified SPCEs," Sensors and Actuators B: Chemical, vol. 140, no. 1, pp. 51-57, 2009.

[9] W.-Y. Su and S.-H. Cheng, "Electrocatalysis and sensitive determination of cysteine at poly(3,4-ethylenedioxythiophene)-modified screen-printed electrodes," Electrochemistry Communications, vol. 10, no. 6, pp. 899-902, 2008.

[10] F. Sekli-Belaidi, P. Temple-Boyer, and P. Gros, "Voltammetric microsensor using PEDOT-modified gold electrode for the simultaneous assay of ascorbic and uric acids," Journal of Electroanalytical Chemistry, vol. 647, no. 2, pp. 159-168, 2010.

[11] Y.-P. Hsiao, W.-Y. Su, J.-R. Cheng, and S.-H. Cheng, "Electrochemical determination of cysteine based on conducting polymers/gold nanoparticles hybrid nanocomposites," Electrochimica Acta, vol. 56, no. 20, pp. 6887-6895, 2011.

[12] N. F. Atta and M. F. el-Kady, "Novel poly(3-methylthiophene)/Pd, Pt nanoparticle sensor: synthesis, characterization and its application to the simultaneous analysis of dopamine and ascorbic acid in biological fluids," Sensors and Actuators B: Chemical, vol. 145, no. 1, pp. 299-310, 2010.

[13] N. F. Atta, M. F. El-Kady, and A. Galal, "Simultaneous determination of catecholamines, uric acid and ascorbic acid at physiological levels using poly(N-methylpyrrole)/Pdnanoclusters sensor," Analytical Biochemistry, vol. 400, no. 1, pp. 78-88, 2010.

[14] I. T. Kim, J. H. Lee, and S. W. Lee, "New low band gap conjugated conducting poly(2-nonylthieno[3,4-d] thiazole): synthesis, characterization, and properties," Bulletin of the Korean Chemical Society, vol. 28, no. 12, pp. 2511-2513, 2007.

[15] P. Attri and E. H. Choi, "Influence of reactive oxygen species on the enzyme stability and activity in the presence of ionic liquids," PLoS One, vol. 8, no. 9, article e75096, 2013.

[16] P. Attri, K. Y. Baik, P. Venkatesu, I. T. Kim, and E. H. Choi, "Influence of hydroxyl group position and temperature on thermophysical properties of tetraalkylammonium hydroxide ionic liquids with alcohols," PLoS One, vol. 9, no. 1, article e86530, 2014. 
[17] P. Attri, S.-H. Lee, S. W. Hwang et al., "Effect of temperature on the interactions between low bandgap polymer and ionic liquids," Thermochimica Acta, vol. 579, pp. 15-21, 2014.

[18] P. Attri, P. Venkatesu, and A. Kumar, "Activity and stability of a-chymotrypsin in biocompatible ionic liquids: enzyme refolding by triethyl ammonium acetate," Physical Chemistry Chemical Physics, vol. 13, no. 7, pp. 2788-2796, 2011.

[19] P. Attri and P. Venkatesu, "Thermodynamic characterization of the biocompatible ionic liquid effects on protein model compounds and their functional groups," Physical Chemistry Chemical Physics, vol. 13, no. 14, pp. 6566-6575, 2011.

[20] P. Attri, P. M. Reddy, P. Venkatesu, A. Kumar, and T. Hofman, "Measurements and molecular interactions for N,N-dimethylformamide with ionic liquid mixed solvents," The Journal of Physical Chemistry B, vol. 114, no. 18, pp. 6126-6133, 2010.

[21] P. Attri and P. Venkatesu, "Exploring the thermal stability of $\alpha$-chymotrypsin in protic ionic liquids," Process Biochemistry, vol. 48, no. 3, pp. 462-470, 2013.

[22] P. Attri, R. Bhatia, B. Arora et al., "Molecular interactions between carbon nanotubes and ammonium ionic liquids and their catalysis properties," Materials Research Bulletin, vol. 58, pp. 6-9, 2014.

[23] P. Attri, T. Sarinont, M. Kim et al., "Influence of ionic liquid and ionic salt on protein against the reactive species generated using dielectric barrier discharge plasma," Scientific Reports, vol. 5, no. 1, article 17781, 2015.

[24] P. Attri, P. Venkatesu, A. Kumar, and N. Byrne, "A protic ionic liquid attenuates the deleterious actions of urea on $\alpha$-chymotrypsin," Physical Chemistry Chemical Physics, vol. 13, no. 38, pp. 17023-17026, 2011.

[25] P. Attri, P. Venkatesu, and T. Hofman, “Temperature dependence measurements and structural characterization of trimethyl ammonium ionic liquids with a highly polar solvent," The Journal of Physical Chemistry B, vol. 115, no. 33, pp. 10086-10097, 2011.

[26] Z.-G. Le, M. Liang, Z.-S. Chen, S.-H. Zhang, and Z.-B. Xie, "Ionic liquid as an efficient medium for the synthesis of quinoline derivatives via $\alpha$-chymotrypsin-catalyzed Friedländer condensation," Molecules, vol. 22, no. 5, p. 762, 2017.

[27] H.-K. Lim and H. Kim, "The mechanism of room-temperature ionic-liquid-based electrochemical CO2 reduction: a review," Molecules, vol. 22, no. 4, p. 536, 2017.

[28] J. Zhang, J. Liu, Y. Zuo, R. Wang, and Y. Xiong, "Preparation of thermo-responsive poly(ionic liquid)s-based nanogels via one-step cross-linking copolymerization," Molecules, vol. 20, no. 9, pp. 17378-17392, 2015.

[29] Y. Zhou, Z. Liu, T. Yuan, J. Huang, and C. Liu, "The synthesis of 2-aminobenzoxazoles using reusable ionic liquid as a green catalyst under mild conditions," Molecules, vol. 22, no. 4, p. 576, 2017

[30] P. Yu, Y. Lin, L. Xiang, L. Su, J. Zhang, and L. Mao, "Molecular films of water-miscible ionic liquids formed on glassy carbon electrodes: characterization and electrochemical applications," Langmuir, vol. 21, no. 20, pp. 9000-9006, 2005.

[31] N. Maleki, A. Safavi, and F. Tajabadi, "High-performance carbon composite electrode based on an ionic liquid as a binder," Analytical Chemistry, vol. 78, no. 11, pp. 3820-3826, 2006.

[32] R. T. Kachoosangi, M. M. Musameh, I. Abu-Yousef et al., "Carbon nanotube-ionic liquid composite sensors and biosensors," Analytical Chemistry, vol. 81, no. 1, pp. 435-442, 2009.
[33] D. W. Hatchett and M. Josowicz, "Composites of intrinsically conducting polymers as sensing nanomaterials," Chemical Reviews, vol. 108, no. 2, pp. 746-769, 2008.

[34] I. T. Kim, G.-C. Kwon, E. H. Choi et al., "Interaction studies between newly synthesized photosensitive polymer and ionic liquids," International Journal of Polymer Science, vol. 2015, Article ID 461974, 8 pages, 2015.

[35] X. Crispin, F. L. E. Jakobsson, A. Crispin et al., "The origin of the high conductivity of poly(3,4-ethylenedioxythiophene)-poly(styrenesulfonate) (PEDOT-PSS) plastic electrodes," Chemistry of Materials, vol. 18, no. 18, pp. 4354-4360, 2006.

[36] J. Ouyang, C. W. Chu, F. C. Chen, Q. Xu, and Y. Yang, "Highconductivity poly(3,4-ethylenedioxythiophene):poly(styrene sulfonate) film and its application in polymer optoelectronic devices," Advanced Functional Materials, vol. 15, no. 2, pp. 203-208, 2005.

[37] M. Döbbelin, R. Marcilla, M. Salsamendi et al., "Influence of ionic liquids on the electrical conductivity and morphology of PEDOT:PSS films," Chemistry of Materials, vol. 19, no. 9, pp. 2147-2149, 2007.

[38] V. Timoshevskii, Y. Ke, H. Guo, and D. Gall, “The influence of surface roughness on electrical conductance of thin $\mathrm{Cu}$ films: an ab initio study," Journal of Applied Physics, vol. 103, no. 11, article 113705, 2008.

[39] V. D. Noto, M. Piga, G. A. Giffin et al., "Influence of anions on proton-conducting membranes based on neutralized nafion 117 , triethylammonium methanesulfonate, and triethylammonium perfluorobutanesulfonate. 1. Synthesis and properties," The Journal of Physical Chemistry C, vol. 116, no. 1, pp. 1361-1369, 2011.

[40] J. W. Jo, S. S. Kim, and W. H. Jo, "Synthesis of thieno[3,4-d]thiazole-based conjugated polymers and HOMO level tuning for high $\mathrm{V}_{\mathrm{OC}}$ photovoltaic cell," Organic Electronics, vol. 13, no. 8, pp. 1322-1328, 2012.

[41] H. N. Hong, H. J. Kim, A. Kim et al., "Tunable intrinsic semiconducting properties of diketopyrrolopyrrole-based copolymers with electron donating thiophene and electron accepting thiazole moieties," Synthetic Metals, vol. 236, pp. 1-7, 2018. 


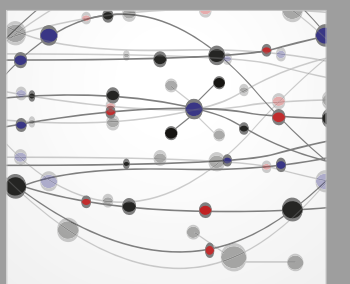

The Scientific World Journal
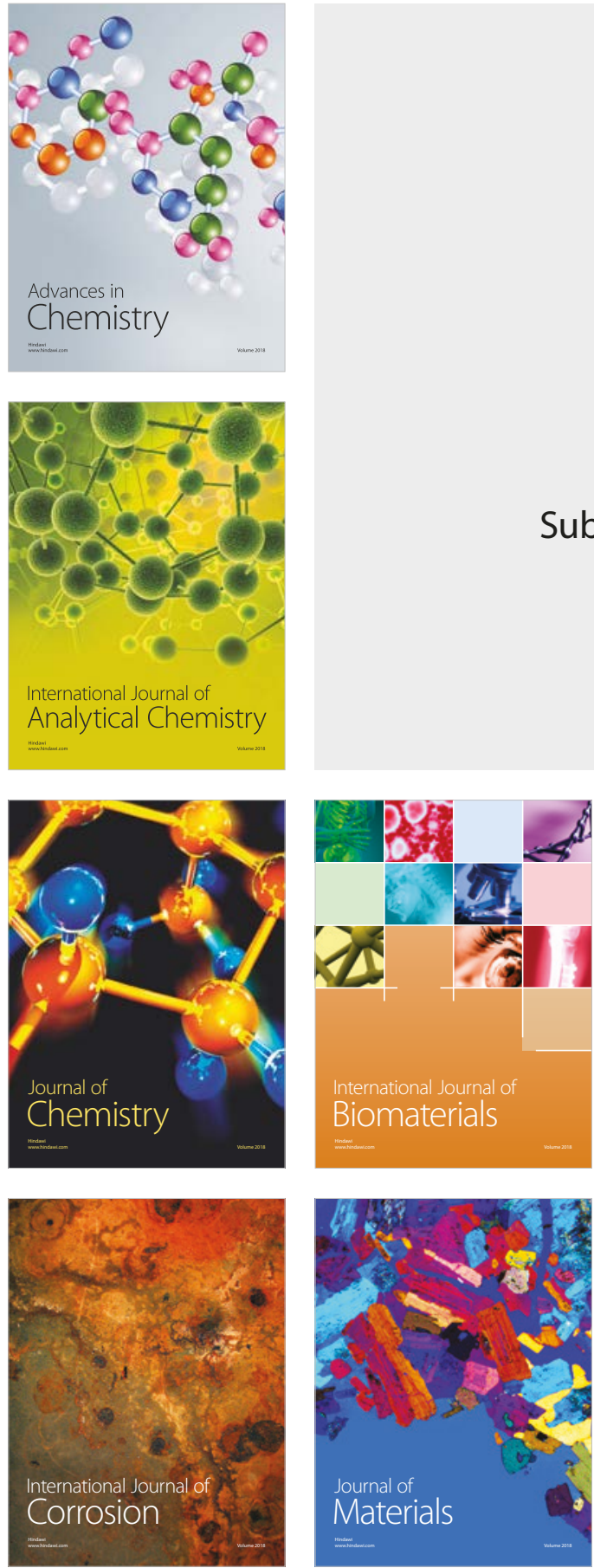

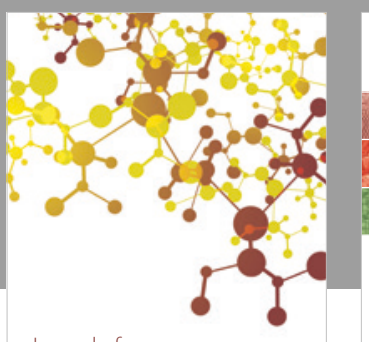

Journal of

Applied Chemistry
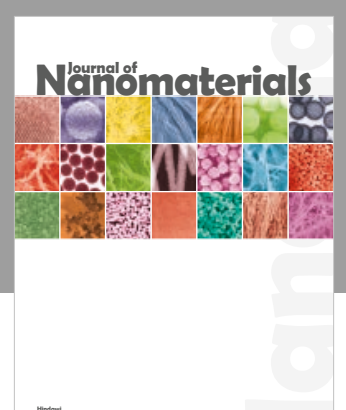

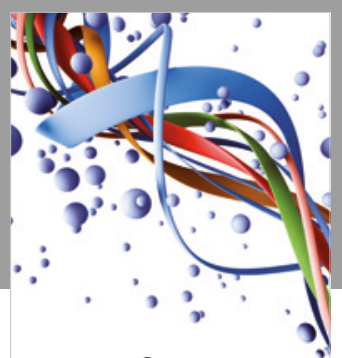

Scientifica

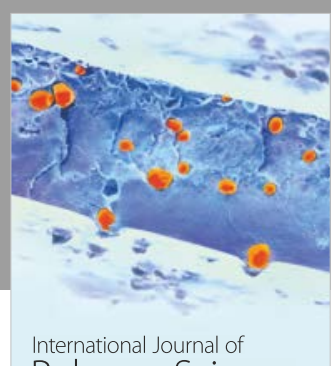

Polymer Science

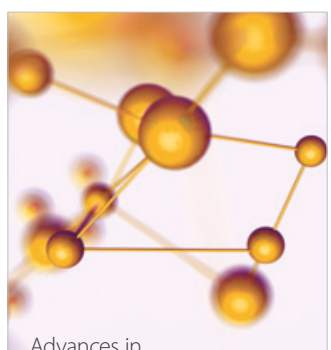

Physical Chemistry
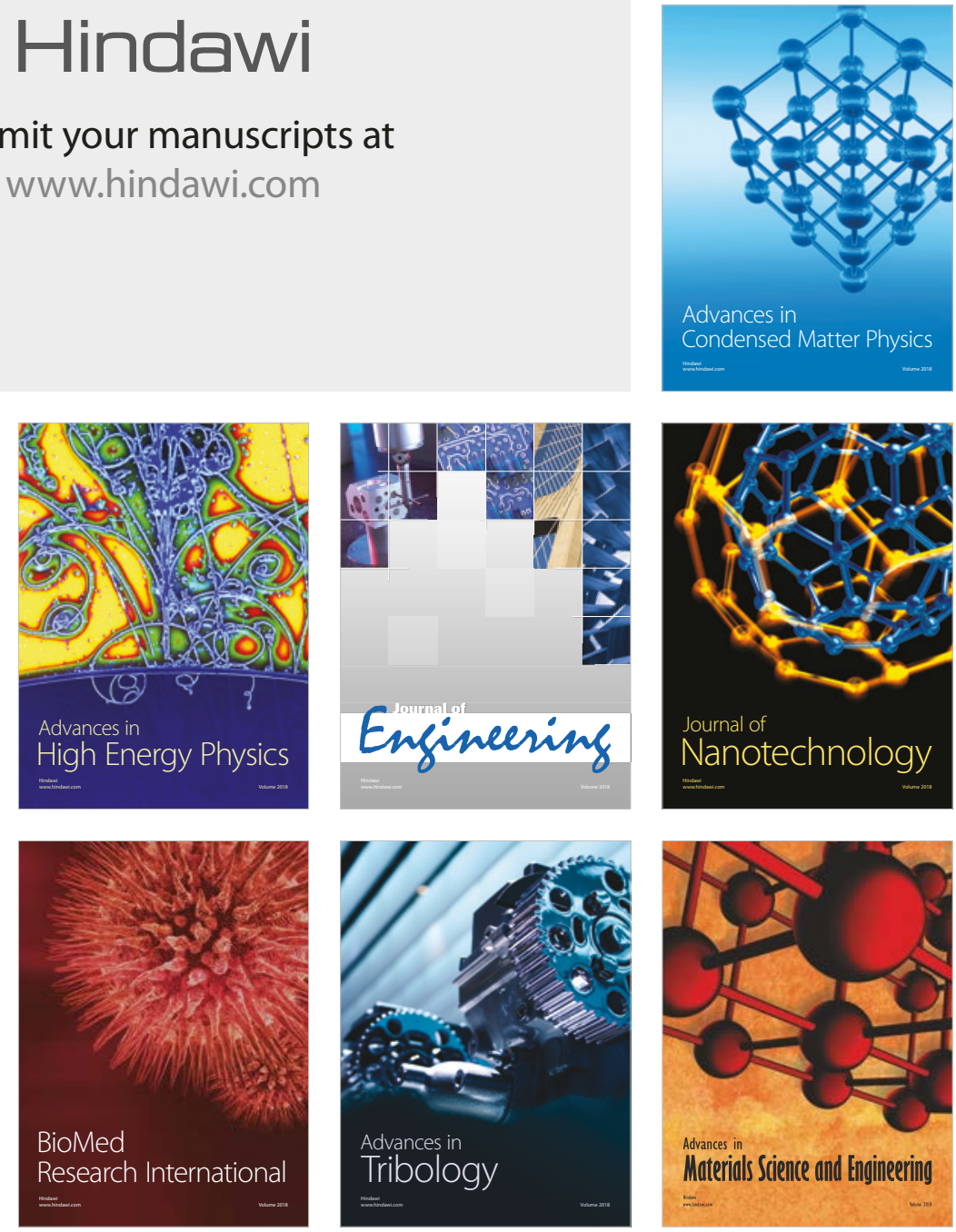